\title{
IDENTIFICATION AND EVALUATION OF RESISTANCE GENES SOURCES OF STEM RUST IN DIFFERENT EGYPTIAN AND CIMMYT WHEAT GENOTYPES USING CONVENTIONAL AND MOLECULAR TECHNIQUES. \\ Abu Aly, A. A. M.; A.A. Shahin; Doaa R. EL-Naggar and Gamalat
} A. Hermas,

Wheat Dis. Res. Dept. St., Institute of Plant Pathology, ARC, Egypt

E-mail: a_aziz_egypt2007@yahoo.com; a.a.shahin@hotmail.com

\section{ABSTRACT}

Wheat stem rust, caused by Puccinia graminis f. sp. tritici, is one of the most destructive diseases of wheat. Resistant varieties can be the simplest, practical, effective and economical method of plant disease control. Development of molecular markers helps to determine stem rust resistance genes ( $\mathrm{Sr}$ genes). The objective of this study was to identify resistance effective genes against the stem rust at seedling and adult stags and to identify Sr genes in eleven genotypes of wheat by molecular markers response of monogenic lines and genotypes of wheat to stem rust reaction. Data at seedling and field studies clustered the genotypes into 4 main categories; (1) resistant at both seedling and adult plant stages monogenic lines, i.e. (Sr24, Sr25, Sr26, Sr31 and Sr32), (2) resistant only at adult stage monogenic lines i.e. (Sr27), (3) scored high susceptibility at both adult and seedling stages monogenic lines ( Sr6, Sr16, Sr17, Sr18, Sr21, Sr22, Sr23, Sr28, Sr29, Sr30, Sr33, Sr34, Sr35, Sr36 and Sr40 and (4) resistant only at seedling stage monogenic line i.e. (Sr37, Sr38 and Sr39). On the other hand, Egyptian cultivars of Sids-13, Gemmeiza-11 and 3 of CIMMYT-8STEMRRSN Lines i.e. line-6043, line -6085 and line-6086 showed resistance at both stages. Meanwhile, Sids-12, Gemmeiza-10, Misr-1 and Misr-2 were resistant at seedling but susceptible at adult plant stage. The rest of the cultivars were susceptible at both stages. In this study, eleven genotypes of wheat were screened with four DNA markers to detect the presence of stem rust resistance genes Sr2, Sr24, Sr26 and Sr31. Stem rust resistance genes Sr2 were present in all varieties tested whereas, Sr24 detected in two local Egyptian cultivar (Sakha 93 and Misr-1) and one line-6085 from (CIMMYT). Sr26 gene markers produced a 250-bp band that observed in 9 genotypes and did not shown in 2 genotypes. Sr31, marker resulted in a 1100-bp fragment in 7 genotypes, this fragment was absent in the remaining 4 genotypes. These results form a basis for mode of resistance study especially to the unknown sources and to mapping those using molecular markers.

Keywords: Stem rust, molecular marker, identifies, resistance genes, susceptibility.

\section{INTRODUCTION}

Under favorable conditions, stem rust epidemic have resulted in as much as $50 \%$ yield losses, whereas yield losses due to Ug99 virulent race can affect $90 \%-100 \%$ of wheat crop (Beard et. al., 2006). Ug99 is the most devastating race of Puccinia graminis f. sp. tritici and it considered as a major threat to wheat production. It first appeared in Uganda in 1999 and now has spread throughout East Africa, Yemen, Sudan, and Iran. Its spread has now been predicted toward North Africa, Middle East Asia, and beyond, raising serious concerns of major epidemics that could destroy wheat crops in various areas (Singh et al., 2008). Two variant strains of Ug99, TTKST and TTSSK, were detected in Kenya in 2006 and 2007, indicating the evolution of 
Ug99. In 2007, there was a severe epidemic in some regions of Kenya by TTKST, and half of the global wheat germplasm that was resistant to Ug99 appeared to be susceptible to this variant (Singh et al., 2008). To date, 50 stem rust resistance genes have been reported in wheat and its wild relatives (McIntosh et al., 2003). Most of these genes are specific to pathogen race except Sr2, which is race-non specific and provides durable resistance (Mclntosh et al., 1995; Singh et al., 2006). Sr2 confers slow rusting, which may not substantially reduce yield losses under severe epidemics. Therefore, deployment of $\mathrm{Sr} 2$ with other rust resistance minor genes, commonly called Sr2-complex, can provide resistance against most of the stem rust races, including Ug99 (Singh et al., 2006).

Molecular markers provide an efficient way to address problems faced in conventional breeding methods. Rust resistance genes can be tagged with tightly linked DNA markers and selection based on these markers improves the efficiency of breeding programs (Todorovska et al., 2009). With the advent of marker-assisted selection (MAS), gene pyramiding, in which genes identified in different genotypes are deployed into a single cultivar that contains desired alleles at more than one locus, has become efficient (Joshi and Nayak, 2010). Several DNA markers linked to various stem rust resistance genes in wheat have been identified and developed. The genes include Sr2 (Spielmeyer et al., 2003; Hayden et al., 2004), (Tsilo et al., 2007), Sr24 (Mago et al., 2005; Olson et al., 2010), Sr25 (Liu et al., 2010), Sr26 (Mago et al., 2005; Liu et al., 2010), Sr31 (Das et al., 2006), Sr35 (Zhang et al., 2010), Sr36 (Tsilo et al., 2008), Sr38 (Helguera et al., 2003), Sr39 (Gold et al., 1999), Sr40 (Shuangye et al., 2009), SrCad (Hiebert et al., 2011), SrWeb (Hiebert et al., 2010), Sr51 (Liu et al., 2011), Sr52 (Qi et al., 2011), and Sr53 (Liu et al., 2011).

There is limited information on the presence/absence of major stem rust resistance genes in local Egyptian genotypes. This information will aid wheat breeders in selecting markers to use in MAS and gene pyramiding to enhance durability of stem rust resistance. This study aimed to identify new sources of resistance to stem rust in 7 Egyptian cultivars and 4 CIMMYT lines.

\section{MATERIALS AND METHODS}

Wheat genotypes used in this study included a set of 25 stem rust resistance genes (Sr2, Sr6, Sr16, Sr17, Sr18, Sr21, Sr22, Sr23, Sr24, Sr25, Sr26, Sr27, Sr28, Sr29, Sr30, Sr31, Sr32, Sr33, Sr34, Sr35, Sr36, Sr37, Sr38, Sr39 and Sr40). Seven local Egyptian wheat cultivars (Sakha-93, Sids12, Sids-13, Gemmiza-10, Gemmiza-11, Misr-1 and Misr-2) and four lines (Line-6043, Line-6086, Line-6107 and Line-6085) from the International Maize and Wheat Improvement Center (CIMMYT) were tested under Egyptian condition.

\section{Stem rust evaluation under greenhouse and field conditions:}

Evaluation of selected accessions for seedling host response against Puccinia graminis Pers. f. sp. tritici was conducted in the greenhouse of Cereal Dis. Div., Plant Pathol. Inst. at Giza during 2012/2013. Method for inoculums preparation, inoculation, incubation, and disease estimation were as 
described by Tervet and Cassel (1951) and Stakman et al. (1962). Seedlings with infection type (IT) based on scale (0-4) was recorded 15 days after inoculation. Seedlings with 0,$0 ;, 1$ and 2 scores were considered resistant and those with high IT scores 3 and 4 were classified as susceptible. Adult plant resistance was evaluated on the same set of materials at two locations (Kafr El-hamam and Sakha research stations) during 2012/2013 growing season, the recommended agricultural practices were applied. Disease severity was assessed using the modified Cobb Scale (Peterson et al., 1948). Infection response was scored as resistant (R), moderately resistant (MR), moderately susceptible (MS) and susceptible (S), as described by Roelfs et al. (1992).

Molecular markers:

DNA extraction:

Total genomic DNA of each wheat cultivar and lines were extracted from leaves following the protocol described by Mago et al. (2005). Samples of $60 \mathrm{mg}$ leaf tissue were digested in liquid nitrogen with a mortar and pestle using i-genomic plant DNA extraction Mini Kit (iNtRON Biotechnology, Inc, Korea Cat. No. 17371) according to manufacturer's instructions. The eluted DNA was stored at $-20^{\circ} \mathrm{C}$.

PCR mixture:

PCR reaction was conducted in reaction volume of $25 \mu \mathrm{l}$. Each PCR mixture $(25 \mu \mathrm{l})$ contains $1 \mu \mathrm{l}$ of $25 \mathrm{ng}$ nucleic acid, $1 \mu \mathrm{l}$ of each primer (10 $\mathrm{pmol}$ ), $12.5 \mu \mathrm{l}$ of GoTag $(\mathrm{R})$ Colorless Master Mix (Promega Corporation, USA) and $9.5 \mu \mathrm{l}$ of Nuclease free water (Promega). $15 \mu \mathrm{l}$ of all PCR products were analyzed by electrophoresis through a $1.5 \%$ agarose gel, stained with ethidium bromide. DNA bands were visualized using a UV Tran illuminator. Sequences of primers are listed in Table (1).

Table 1: List of stem rust resistance genes sequences of primers.

\begin{tabular}{|c|c|c|c|}
\hline Gene & marker & Primer sequence & Reference \\
\hline Sr2 & $\operatorname{csSr} 2$ & $\begin{array}{l}\text { csSr2-F 5'- CAA GGG TTG CTA GGA TTG GAA AAC -3' } \\
\text { csSr2-R 5'- AGA TAA CTC TTA TGA TCT TAC ATT TTT CTG -3, }\end{array}$ & Mago et al., 2011 \\
\hline Sr24 & Sr24\#12 & $\begin{array}{l}\text { lr24\#12-F 5'- CAC CCG TGA CAT GCT CGT A -3' } \\
\text { Sr24\#12-R 5'- AAC AGG AAA TGA GCA ACG ATG T -3' }\end{array}$ & Mago et al., 2005 \\
\hline Sr26 & Sr26\#43 & $\begin{array}{l}\text { Sr26E\#3-F 5'- AAT CGT CCA CAT TGG CTT CT - - } \\
\text { Sr26\#43-R 5'- CGC AAC AAA ATC ATG CAC TA -3' }\end{array}$ & Mago et al.,2005 \\
\hline Sr31 & lag95 & $\begin{array}{l}\text { lag95-F } 5 \text { 5'-CTCTGTGGATAGTTACTTGATCGA 3' } \\
\text { lag95-R } \\
\text { 5'- CCTAGAACATGCATGGCTGTTACA } 3^{\prime}\end{array}$ & Mago et al., 2002 \\
\hline
\end{tabular}

\section{RESULTS}

The objective of this study was to identify $\mathrm{Sr}$ resistance genes ( $\mathrm{Sr}$, Sr24, Sr26 and Sr31) in 7 local Egyptian wheat cultivars and in 4 lines from CIMMYT, so as to facilitate future Sr gene pyramiding against stem rust.

\section{Seedling and adult tested monogenic lines and local cultivars against} stem rust:

Data in Table (2) indicated that, at seedling stage the monogenic lines that exhibited high ITs (3 and 4) were Sr6, Sr18, Sr21, Sr28, Sr36 and Sr40 with efficacy of $20 \%$, followed by Sr16, Sr17, Sr22, Sr30 and Sr34 with efficacy of $40 \%$. These monogenic lines were not effective against five races under greenhouse conditions. While monogenic lines which exhibited low ITs $(0,0 ;, 1$ and 2) indicated that Sr2, Sr24, Sr25, Sr26, Sr31, Sr32, Sr37, Sr38 
and Sr39 gave high efficacy (100\%), which were the most effective genes against five races, followed by Sr27 and Sr29 (80\%).

Table 2: Response of some monogenic lines to stem rust reaction at seedling and adult stage.

\begin{tabular}{|c|c|c|c|c|c|c|c|c|c|}
\hline \multirow{2}{*}{ No. } & \multirow{2}{*}{ Genes } & \multicolumn{5}{|c|}{$\begin{array}{l}\text { Infection type to five pathotypes at seedling } \\
\text { stage in Giza greenhouse }\end{array}$} & \multirow{2}{*}{$\begin{array}{c}\text { Efficacy } \\
\%\end{array}$} & \multicolumn{2}{|c|}{$\begin{array}{l}\text { Disease severity } \\
\text { at adult stage in } \\
\text { two location }\end{array}$} \\
\hline & & RSPCB & THRTC & TTTPB & BBBBC & RHTTC & & Sakha & $\begin{array}{l}\text { Kaferel } \\
\text { hamam }\end{array}$ \\
\hline 1 & Sr2 & 1 & 2 & 2 & 1 & 2 & 100 & TrMR & TrMR \\
\hline 2 & Sr6 & 3 & 4 & 4 & 0 & 4 & 20 & $10 S$ & $40 S$ \\
\hline 3 & Sr16 & 0 & 4 & 4 & 1 & 4 & 40 & $30 s$ & $60 S$ \\
\hline 4 & Sr17 & 3 & 1 & 4 & 0 & 4 & 40 & $30 S$ & $40 S$ \\
\hline 5 & Sr18 & 0 & 3 & 4 & 4 & 4 & 20 & $20 S$ & $50 S$ \\
\hline 6 & Sr21 & 3 & 4 & 4 & 1 & 4 & 20 & $30 S$ & $60 S$ \\
\hline 7 & Sr22 & 2 & 4 & 4 & 0 & 4 & 40 & $20 S$ & $50 S$ \\
\hline 8 & Sr23 & 1 & 0 & 4 & 0 & 4 & 60 & $10 \mathrm{~S}$ & $30 S$ \\
\hline 9 & Sr24 & 1 & 1 & 1 & 0 & 1 & 100 & $10 \mathrm{R}$ & 10R/MR \\
\hline 10 & Sr25 & 0 & 1 & 0 & 0 & 2 & 100 & $5 \mathrm{MR}$ & 10MR \\
\hline 11 & Sr26 & 2 & 2 & 1 & 0 & 2 & 100 & $10 \mathrm{MR}$ & $20 \mathrm{MR}$ \\
\hline 12 & Sr27 & 2 & 4 & 0 & 0 & 1 & 80 & 30MR & 40MR \\
\hline 13 & Sr28 & 3 & 4 & 4 & 0 & 4 & 20 & $30 S$ & $50 S$ \\
\hline 14 & Sr29 & 0 & 0 & 4 & 0 & 1 & 80 & $10 S$ & $50 S$ \\
\hline 15 & Sr30 & 4 & 0 & 4 & 0 & 4 & 40 & $10 S$ & $30 S$ \\
\hline 16 & Sr31 & 0 & 0 & 0 & 0 & 1 & 100 & $10 \mathrm{R}$ & $20 M R$ \\
\hline 17 & Sr32 & 2 & 0 & 2 & 2 & 1 & 100 & 20MR & 40MR \\
\hline 18 & Sr33 & 3 & 0 & 0 & 0 & 4 & 60 & $5 \mathrm{MS}$ & $10 \mathrm{MS}$ \\
\hline 19 & Sr34 & 2 & 4 & 4 & 0 & 4 & 40 & $20 S$ & $40 S$ \\
\hline 20 & Sr35 & 2 & 0 & 4 & 0 & 3 & 60 & $10 \mathrm{~S}$ & $20 S$ \\
\hline 21 & Sr36 & 3 & 4 & 4 & 0 & 4 & 20 & $5 S$ & $20 S$ \\
\hline 22 & Sr37 & 1 & 1 & 1 & 0 & 2 & 100 & $10 S$ & $30 s$ \\
\hline 23 & Sr38 & 2 & 0 & 2 & 2 & 0 & 100 & $5 \mathrm{MS}$ & $5 S$ \\
\hline 24 & Sr39 & 2 & 0 & 0 & 0 & 0 & 100 & $10 \mathrm{~S}$ & $50 S$ \\
\hline 25 & Sr40 & 2 & 4 & 4 & 4 & 4 & 20 & $30 \mathrm{~S}$ & $40 S$ \\
\hline
\end{tabular}

Infection type (IT) based on a 0-4 scale.

$R=$ resistant, $M R=$ moderately resistant, $\mathrm{Tr}=$ Trace, $\mathrm{S}=$ susceptible and $\mathrm{MS}=$ moderately susceptible.

Table 3: Response of 7 Egyptian wheat cultivars and 4 lines from CIMMYT to stem rust at seedling and adult stages under Egyptian conditions.

\begin{tabular}{lccccc}
\hline & & \multicolumn{2}{c}{$\begin{array}{c}\text { Infection type of two races } \\
\text { at seedling stage }\end{array}$} & \multicolumn{2}{c}{$\begin{array}{c}\text { Disease severity at adult } \\
\text { stage in two locations }\end{array}$} \\
\cline { 2 - 6 } & Entries & TTTPB & RHTTC & Sakha & $\begin{array}{c}\text { Kaferel } \\
\text { hamam }\end{array}$ \\
\hline 1 & Sakha-93 & 4 & 3 & $10 \mathrm{~S}$ & $20 \mathrm{~S}$ \\
2 & Sids-12 & 2 & 1 & $5 \mathrm{~S}$ & $20 \mathrm{~S}$ \\
3 & Sids-13 & 2 & 2 & 0 & TMR \\
4 & Gemmeiza-10 & 1 & 2 & $10 \mathrm{~S}$ & $20 \mathrm{~S}$ \\
5 & Gemmeiza-11 & 2 & 2 & 0 & 0 \\
6 & Misr-1 & 2 & 2 & $10 \mathrm{~S}$ & $20 \mathrm{~S}$ \\
7 & Misr-2 & 3 & 2 & $10 \mathrm{~S}$ & $30 \mathrm{~S}$ \\
8 & Line-6043 & 2 & 2 & 0 & 0 \\
9 & Line-6086 & 1 & 2 & 0 & 0 \\
10 & Line-6107 & 3 & 3 & $5 \mathrm{R}-\mathrm{MR}$ & $10 \mathrm{MR}$ \\
11 & Line-6085 & 2 & 2 & 0 & 0 \\
\hline
\end{tabular}

Infection type (IT) based on a 0-4 scale.

$\mathbf{R}=$ resistant, $M R=$ moderately resistant, $\operatorname{Tr}=$ Trace, $S=$ susceptible and MS = moderately susceptible

Data in Table (2) indicated also that, at adult stage the monogenic lines (Sr24, Sr25, Sr26 and Sr31) exhibited mostly R to MR infection 
responses with relatively low disease severity in the field at both locations. Susceptible infection response with high disease severity was observed on the monogenic lines (Sr6, Sr16, Sr17, Sr18, Sr21, Sr22, Sr23, Sr28, Sr29, Sr30, Sr34, Sr35, Sr36, Sr37, Sr38, Sr39 and Sr40) at both locations.

On other hand, resistances of the eleven genotypes of wheat against stem rust at seedling and adult stages at two locations were shown in Table (3). Sids-13, Gemmeiza-11, Line-6043, line-6085 and line-6086 showed resistance at both stages. Meanwhile, Sids-12, Gemmeiza-10, Misr-1 and Misr-2 were resistant at seedling but susceptible at adult stage. On the other hand the line-6107 was susceptible at seedling stage but was resistant at adult stage. The rest of the cultivars were susceptible at both stages.

Molecular markers:

Seven Egyptian wheat cultivars (Sakha-93, Sids-12, Sids-13, Gemmeiza-10, Gemmeiza-11, Misr-1, and Misr-2) and four lines (Line-6043, line-6086, line-6107 and line-6085) from the CIMMYT and four monogenic lines (Sr2, Sr24, Sr26 and Sr31) were chosen as resistant plant materials ( $\mathrm{Sr}$ genes) to detect stem rust resistance genes using molecular markers. In this study, $\mathrm{Sr}$ specific primer was used to detect the presence/absence of $\mathrm{Sr}$ gene. The polymorphic survey revealed that the marker for Sr2 was identified as a fragment of $310 \mathrm{bp}$ in eleven genotypes as shown in Figure (1). The marker for Sr24 was identified as a fragment of 500bp in three genotypes only (Sakha-93, Misr-1 and line-6085), while other listed genotypes did not show the presence of Sr24 Fig. (2). The polymorphic screening of the eleven genotypes revealed that, the marker for Sr26 was identified as a fragment of 250bp in nine cultivars i.e. Sakha-93, Sids-12, Sids-13, Gemmeiza-10, Gemmeiza-11, Misr-1, Misr-2 and two lines i.e. line-6043 and line-6107. While two tested genotypes line-6068 and line-6085 did not show the presence of Sr26 Fig.(3). The marker for Sr31 was identified as a fragment of 1100bp in all Egyptian cultivars except cv. Sids-13. While all CIMMYT lines did not show the presence of Sr31 except line 6043 (Fig. 4).

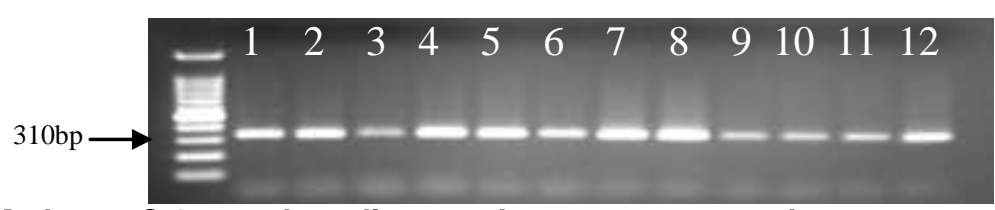

Fig.1. Marker csSr2 tested on diverse wheat genotypes and run on an agarose gel. Lanes: (1) monogenic Sr2, (2) Sakha-93, (3) Sids-12, (4) Sids-13, (5) Gemmeiza-10, (6) Gemmeiza-11, (7) Misr-1, (8) Misr-2, (9) Line-6043,(10) Line-6068, (11) Line-6107 and (12) Line-6085. The arrow showed the fragment which is associated with Sr2.

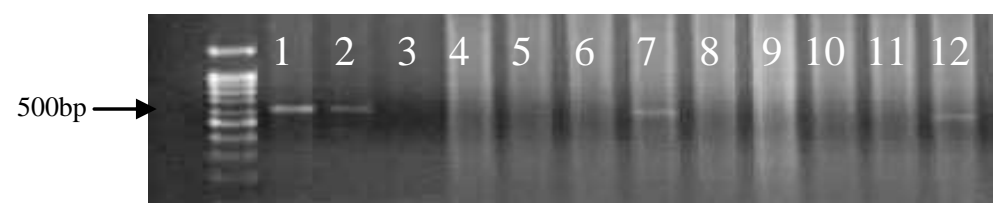

Fig.2. Marker Sr24\#12 tested on diverse wheat genotypes and run on an agarose gel. Lanes: (1) monogenic Sr24, (2) Sakha-93, (3) Sids-12, (4) Sids-13, (5) 
Gemmeiza-10, (6) Gemmeiza-11, (7) Misr-1, (8) Misr-2, (9) Line-6043, (10) Line-6068, (11) Line-6107 and (12) Line-6085. The arrow showed the fragment which is associated with Sr24.

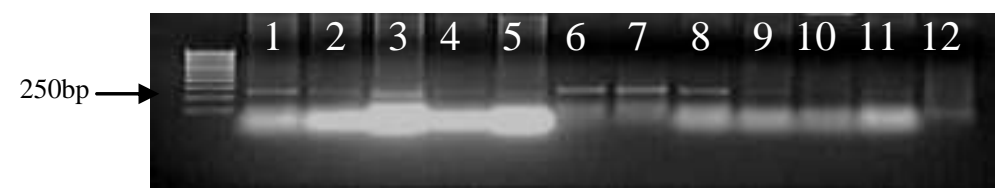

Fig.3. Marker Sr26\#43 tested on diverse wheat genotypes and run on an agarose gel. Lanes: (1) monogenic Sr26, (2) Sakha-93, (3) Sids-12, (4) Sids-13, (5) Gemmeiza-10, (6) Gemmeiza-11, (7) Misr-1, (8) Misr-2, (9) Line-6043, (10) Line-6068, (11) Line-6107 and (12) Line-6085. The arrow showed the fragment which is associated with Sr26.

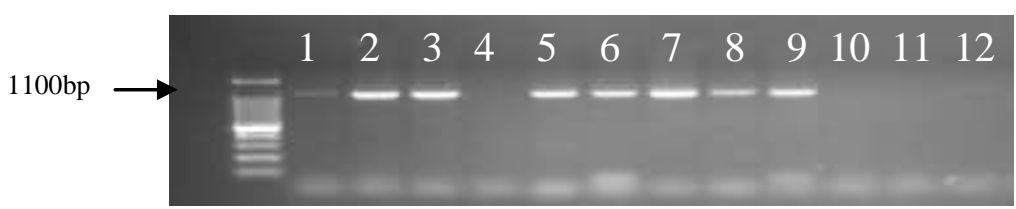

Fig.4. Marker iag95 tested on diverse wheat genotypes and run on an agarose gel. Lanes: (1) monogenic Sr31, (2) Sakha-93, (3) Sids-12, (4) Sids-13, (5) Gemmeiza-10, (6) Gemmeiza-11, (7) Misr-1, (8) Misr-2, (9) Line-6043, (10) Line-6068, (11) Line-6107 and (12) Line-6085. The arrow showed the fragment which is associated with Sr31.

Table 4. Sr genes detected with PCR based markers in 7 Egyptian wheat cultivars and 4 CIMMYT wheat lines.

\begin{tabular}{lcccc}
\hline Genotypes & Sr2 & Sr24 & Sr26 & Sr31 \\
\hline Sakha-93 & + & + & + & + \\
Sids-12 & + & - & + & + \\
Sids-13 & + & - & + & + \\
Gemmeiza-10 & + & - & + & + \\
Gemmeiza-11 & + & - & + & + \\
Misr-1 & + & + & + & + \\
Misr-2 & + & - & + & - \\
Line-6043 & + & - & - & - \\
Line-6068 & + & - & + & - \\
Line-6107 & + & + & - & + \\
Line-6085 & + & + & + \\
\hline
\end{tabular}

$(+)=$ presence of $\mathrm{Sr}$ gene in wheat cultivars and $(-)=$ absence of $\mathrm{Sr}$ gene in wheat genotype

\section{DISCUSSION}

The new races overcome the resistance of widely deployed stem rust resistance genes, especially Sr31. Development of resistant wheat varieties is the most economic method for controlling the disease. To date, more than 45 stem rust resistance Sr's (genes) (Mclntosh et al., 2003) were identified. In Egypt during many growing seasons, samples were collected from trap nurseries and farmer fields. Gene pyramiding using conventional method is difficult and time consuming because it requires simultaneous tests of the same wheat breeding materials with several different rust races before making selection. The development of molecular markers for specific stem rust genes allows the detection of these genes independently of the 
phenotype. Molecular markers can be used in marker-assisted selection for an efficient combination of genes in the pyramiding strategy to create a more durable resistance (Feuillet et al., 1995). In the past 50 years, a number of $\mathrm{Sr}$ genes have been identified and incorporated into wheat genomes through chromosome engineering. Sr22, Sr25, Sr27, Sr32, Sr33, Sr35, Sr37, Sr39, Sr40, Sr44, Sr45, and Sr46 and few unnamed genes are still resistant to Ug99 and its derivatives (Xu et al., 2008).

The present study was conducted to determine the reaction type of the genotypes varies from resistant $(R)$ to susceptible (S). The seedling and adult tests clustered the wheat genotypes into four main categories; 1) resistant at both seedling and adult plant stages monogenic lines (Sr24, Sr25, Sr26, Sr27, Sr31 and Sr32, 2) resistant only at adult stage monogenic lines (Sr27), 3) high susceptibility at both seedling and adult stages monogenic lines (Sr6, Sr16, Sr17, Sr18, Sr21, Sr22, Sr23, Sr28, Sr29, Sr30, Sr33, Sr34, Sr35, Sr36 and Sr40) and 4) resistant only at seedling stage monogenic line (Sr37, Sr38 and Sr39). On other hand wheat cultivars and lines of Sids-13, Gemmeiza-11, Line-6043, line-6085 and line-6086 showed resistance at both stages. Meanwhile, Sids-12, Gemmeiza-10, Misr-1 and Misr-2 were resistant at seedling but susceptible at adult stage. The rest of the cultivars were susceptible at both stages. The lines which show resistance at both seedling and adult plant stages are mainly due to major genes.

Sr2 found in all tested genotypes with a diagnostic band of $310 \mathrm{bp}$ amplified and indicate the presence of Sr2 gene. Although this gene alone is capable of reducing the level of infection and slow rusting resistance gene reported by (Singh et al., 2011). The presence of Sr2 in some of the land races (Haile et al., 2013) also strengthen this fact and showed that Ethiopian cultivated tetraploid wheat accessions are still good sources of stem rust resistance. Sr2, APR to Ug99 races conferred by Sr2 on chromosome 3BS was validated in at least six recombinant inbred line populations characterized by CIMMYT (Bhavani et al., 2011), as well as in several other research efforts. An improved marker for Sr2 is available (Mago et al., 2011), and continued efforts to develop "perfect" markers are underway. Significant interaction of markers linked to Sr2 with markers linked to other resistance loci was detected in multiple association mapping panels (Yu et al., 2011 and 2012).

Many CIMMYT and other varieties internationally contain this gene in combination with other sources of resistance. Sr2 is considered by many to be the foundation of APR breeding efforts (Liu et al., 2010). DNA markers for Sr25 were identified enabling selection of this Thinopyrum ponticum-derived alien resistance on chromosome 7DL. CIMMYT germplasm containing Sr25 and presumably Lr19 in combination with Sr2 was recently released in Afghanistan (Muqawim 2009), Egypt (Misr-1, and Misr-2) and Pakistan (NR356).

Sr24 resistance gene confers resistance to stem rust but not to its variants. Our results showed the absence of this gene in 9 genotypes and its presence in one local Egyptian cultivar (Sakha-93) and one line from CIMMYT (Line-6085). Therefore, deployment of this gene in the Egyptian cultivars should be encouraged. This will provide resistance to other 
prevalent Puccinia graminis $\mathrm{f}$. $\mathrm{sp}$ tritici races and may provide residual resistance to its variants as suggested by Knott (2008). Moreover, Sr24 gene is also useful due to its linkage with Lr24. Klindworth et al. (2012) reported the occurrence of this gene in U.S. winter wheat, which can be used as source of Sr24.

Sr26 gene marker which produced a 250bp band was observed in nine genotypes and was absent in two genotypes with Sr26. New translocation stocks with reduced Thinopyrum ponticum chromatin containing Sr26 on chromosome 6AL were identified. PCR-based markers that allow for routine detection can be used to identify these smaller translocations (Liu et al., 2010). Australian varieties with the original translocation have been grown for over 30 years (Mclntosh et al. 1995). Deployment of Sr26 is not documented in the rest of the world presumably due to real or perceived evidence of linkage drag preventing realization of other traits, but many programs are currently using the new translocation derivatives in resistance breeding efforts.

Results from iag95 marker were used to detect Sr31. Marker resulted in an 1100bp fragment which was observed in 7 genotypes and was absent in the remaining four genotypes. Before the emergence of Ug99, stem rust resistance was maintained mainly by Sr31 in most of the countries around the world except Australia (Singh et al., 2008). Our results showed the presence of Sr31 in these genotypes indicating that Sr31 may be effective against Egypt stem rust races. Pretorius et al. (2012) reported that marker iag95 has been successfully validated on South African germplasm also.

Marker assisted analysis of these resistance genes is important to Egypt breeders because they cannot directly evaluate resistance to Ug99 and associated foreign races in their breeding. Using molecular markers in pyramiding 2-3 genes of Sr24, Sr26, Sr31 and SrR has been reported (Mago et al., 2011). Sr22, Sr26, and Sr35 conferred resistance to Ug99 and other important races (Singh et al., 2011). Markers for these genes could then aid in selecting APR, pyramiding R-genes and in combining APR genes with $\underline{R}$ genes (Yu et al., 2011). Good example are varieties released in Egypt, Afghanistan and Pakistan whose resistance is based on single race-specific gene (Sr25) and slow rusting resistance gene (Sr2) (Singh et al., 2011).

\section{REFERENCE}

Beard, C.; K. Jayasena; G. Thomas and R. Loughman (2006). Managing stem rust of wheat. Plant Pathology, Department of Agriculture, Western Australia. Farmnote73/2004.

Bhavani, S.; R.P. Singh; O. Argillier; J. Huerta-Espino; S. Singh; P. Njau; S. Brun; S. Lacam and N. Desmouceaux (2011). Mapping durable adult plant stem rust resistance to the race Ug99 group in six CIMMYT wheats. In: McIntosh RA (ed) BGRI 2011 Technical Workshop. Borlaug Global Rust Initiative, St Paul, MN, USA, pp. 43-5.

Das, K.B.; A. Saini; S.G. Bhagwat and N. Jawali. (2006). Development of SCAR markers for identification of stem rust resistance gene Sr31 in the homozygous or heterozygous condition in bread wheat. Plant Breed., 125: 544-549. 
Feuillet C.; G. Schachermayr and B. Keller (1995). Molecular markers for the detection of the wheat leaf rust resistance gene Lr10 in diverse genetic backgrounds. Mol. Breed., 3: 65-74.

Gamalat A. Hermas; I.A. Youssef; A.A. Shahin and Hoda M. Diab. (2013). Physiological specialization of Puccinia graminis f. sp. tritici and probable genes for resistance in 13 Egyptian wheat varieties during 2009/2010. Egypt. J. of App. Sci., 28 (10): 325-344.

Gold, J.; D. Harder; F.T. Smith; T. Aung and J. Procunier. (1999). Development of a molecular marker for rust resistance genes Sr39 and Lr35 in wheat breeding lines. Electron. J. Biotechnol., 2: 35-40.

Haile, J.K., K. Hammer; A. Badebo; R.P. Singh and M.S. Röder (2013). Haplotype analysis of molecular markers linked to stem rust resistance genes in Ethiopian improved durum wheat varieties and tetraploid wheat landraces. Genet. Resour. Crop Evol., 60: 853-864.

Hayden, M.J.; H. Kuchel and K.J. Chalmers (2004). Sequence tagged microsatellites for the Xgwm533 locus provide new diagnostic markers to select for the presence of stem rust resistance gene Sr2 in bread wheat (Triticum aestivum L.). Theor. Appl. Genet. 109: 1641-1647.

Helguera, M.; A.I. Khan; J. Kolmer; D. Lijavetzky; L. Zhong-Qi, and J. Dubcovsky (2003). PCR assays for the Lr37-Yr17-Sr38 cluster of rust resistance genes and their use to develop isogenic hard red spring wheat lines. Crop Sci., 43: 1839-1847.

Hiebert, C.W.; T.G. Fetch; Jr. and T. Zegeye (2010). Genetics and mapping of stem rust resistance to Ug99 in the wheat cultivar Webster. Theor. Appl. Genet., 121: 65-69.

Hiebert, C.W.; T.G. Fetch; T. Zegeye; J.B. Thomas; D.J. Somers; D.G. Humphreys; B.D. McCallum; S. Cloutier; D. Singh and D.R. Knott (2011). Genetics and mapping of seedling resistance to Ug99 stem rust in Canadian wheat cultivars 'Peace' and 'AC Cadillac'. Theor. Appl. Genet., 122: 143-149.

Joshi, K.R. and S. Nayak (2010). Gene pyramiding- A broad spectrum technique for developing durable stress resistance in crops. Biotechnol. Mol. Biol., 5: 51-60.

Klindworth, D.L.; Z. Niu; S. Chao; T.L. Friesen; J.D. Faris; X. Cai and S.S. Xu (2012). Introgression and characterization of a goatgrass gene for a high level of resistance to Ug99 stem rust in tetraploid wheat. Genes, Genomes, Genetics, 2: 665-673.

Knott, D.R. (2008). The genomics of stem rust resistance in wheat. In: R. Appels et al., editors, Proceedings of the $11^{\text {th }}$ International Wheat Genetics Symposium, Sydney, Australia. 24-29 Aug. 2008. p. 415-417.

Liu, S.; L.X. Yu; R.P. Singh; Y. Jin; M.E. Sorrells and J.A. Anderson (2010). Diagnostic and co-dominant PCR markers for wheat stem rust resistance genes Sr25 and Sr26. Theor. Appl. Genet., 120: 691-697.

Liu, W.; M. Rouse; B. Friebe; Y. Jin; B. Gill and M.O. Pumphrey (2011). Discovery and molecular mapping of a new gene conferring resistance to stem rust, Sr53, derived from Aegilops geniculata and characterization of spontaneous translocation stocks with reduced alien chromatin. Chromosome Res., 19: 669-682.

Mago, R; W. Spielmeyer; G.J. Lawrence; E.S. Lagudah; J.G. Ellis and A. Pryor (2002). Identification and mapping of molecular markers linked to rust resistance genes located on chromo-some $1 \mathrm{RS}$ of rye using wheat-rye translocation lines. Theor. Appl. Genet., 104: 1317-1324.

Mago, R; H.S. Bariana; I.S. Dundas; W. Spielmeyer; G.J. Lawrence; A.J. Pryor and J.G Ellis (2005). Development of PCR markers for the 
selection of wheat stem rust resistance genes Sr24 and Sr26 in diverse wheat germplasm. Theor. Appl. Genet., 111: 496-504.

Mago, R; G. Brown-Guedira; S. Dreisigacker; J. Breen; Y. Jin; R. Singh; R. Appels; E.S. Lagudah; J. Ellis and W. Spielmeyer (2011). An accurate DNA marker assay for stem rust resistance gene Sr2 in wheat. Theor. Appl. Genet., 122: 735-744.

McIntosh, R.A.; Y. Yamazaki; K.M. Devos; J. Dubcovsky; J. Rogers and R. Appels (2003). Catalogue of gene symbols for wheat. Proc. $10^{\text {th }}$ Inter. Wheat Genet. Symp., Vol. 5. Instituto Sperimentale per la Cerealcoltura, Rome.

McIntosh, R.A.; C.R. Wellings and R.F. Park (1995). Wheat rusts, an atlas of resistance genes. CSIRO, Melbourne, Australia.

Olson, L.E.; G.B. Guedira; D.S. Marshall; Y. Jin; M. Mergoum; L. Lowe and J. Dubcovsky (2010). Genotyping of U.S. wheat germplasm for presence of stem rust resistance genes Sr24, Sr36 and Sr1RS Amigo. Crop Sci. 50: 668-675.

Peterson, R.F.; A. B. Campbell and A.E. Hannah (1948). A diagrammatic scale for estimating rust severity on leaves and stems of cereals. Can. J. Res. Sect. C., 26: 496-500.

Pretorius, Z.A.; Y. Jin; C.M. Bender; L. Herselman and R. Prins (2012). Seedling resistance to stem rust race Ug99 and marker analysis for Sr2, Sr24 and Sr31 in South African wheat cultivars and lines. Euphytica, 186: 15-23.

Qi, L.L.; M.O. Pumphrey; B. Friebe; C. Qian; R.L. Bowden; M.N. Rouse; Y. Jin and B.S. Gill (2011). A novel Robertsonian event leads to transfer of a stem rust resistance gene (Sr52) effective against race Ug99 from Daspyrum villosum into wheat. Theor. Appl. Genet., 123: 159-167.

Roelfs, A.P.; R.P. Singh and E.E. Saari (1992). Rust Diseases of Wheat: Concepts and methods of disease management. Mexico, D.F.: CIMMYT, 81.

Shuangye, W.; M. Pumphrey and G. Bai (2009). Molecular mapping of stemrust resistance gene Sr40 in wheat. Crop Sci., 49: 1681-1686.

Singh, R.P.; D.P. Hodson; Y. Jin; J.H. Espino; M.G. Kinyua; R. Wanyera; P. Njau, and R.W. Ward (2006). Current status, likely migration and strategies to mitigate the threat to wheat production from race Ug99 (TTKS) of stem rust pathogen. CAB Rev. Perspect Agric. Vet. Sci. Nutr. Nat. Resour., 1(054):13.

Singh, R.P.; D.P. Hodson; J. Huerta-Espino; Y. Jin; S. Bhavani; P. Njau; S. Herrera Foessel; P.K. Singh; S. Singh and V. Govindan (2011). The emergence of Ug99 races of stem rust fungus is a threat to world wheat production. Annu. Rev. Phytopathol., 49: 465-481.

Singh, R.P.; D.P. Hodson; J. Huerta-Espino; Y. Jin; P. Njau; R. Wanyera; S.A. Herrera-Foessel and R.W. Ward (2008). Will stem rust destroy the world's wheat crop Adv. Agron., 98: 271-309.

Spielmeyer, W; P.J. Sharp and E.S. Lagudah (2003). Identification and validation of markers linked to broad-spectrum stem rust resistance gene Sr2 in wheat (Triticum aestivum L.). In: Crop Sci., 43: 333-336.

Stakman, E.C.; D.M. Stewart and W.Q. Loegering (1962). Identification of physiologic races of Puccinia graminis var. tritici A.R.S. USDA Agric. Res. Serv. Bull. E. 617-53 pp.

Tervet, I. and Cassel, R.C. (1951). The use of cyclon separation in race identification of cereal rusts. Phytopathology, 41: 282- 285. 
Todorovska, E.; N. Christov; S. Slavov; P. Christova and D. Vassilev (2009). Biotic stress resistance in wheat-Breeding and genomic selection implications. Biotechnol. Biotechnol. Eq., 23: 1417-1426.

Tsilo, J.T., Y. Jin and J.A. Anderson (2007). Microsatellite markers linked to stem rust resistance allele Sr9a in wheat. Crop Sci., 47: 2013-2020.

Tsilo, T.J.; Y. Jin and J.A. Anderson (2008). Diagnostic microsatellite markers for the detection of stem rust resistance gene Sr36 in diverse genetic backgrounds of wheat. Crop Sci., 48: 253-261.

Xu, S.S.; I.S. Dundas; M.O. Pumphrey; Y. Jin; J.D. Faris; X. Cai; L.L. Qi; B.R. Friebe and B.S. Gill (2008). Chromosome engineering to enhance utility of alien-derived stem rust resistance. In: Appels R, Eastwood R, Lagudah $\mathrm{E}$.

Yu, L.X.; A. Lorenz; J. Rutkoski; R.P. Singh; S. Bhavani; J. Huerta-Espino and M.E. Sorrells (2011). Association mapping and gene-gene interaction for stem rust resistance in CIMMYT spring wheat germplasm. Theor. Appl. Genet., 123:1257-1268.

Yu, L.X; A. Morgounov; R. Wanyera; M. Keser; S.K. Singh and M. Sorrells (2012). Identification of Ug99 stem rust resistance loci in winter wheat germplasm using genome-wide association analysis. Theor. Appl. Genet., 125: 749-758.

Zhang, W.; E. Olson; C. Saintenac; M. Rouse; Z. Abate; Y. Jin; E. Akhunov; M. Pumphrey and J. Dubcovsky (2010). Genetic maps of stem rust resistance gene Sr35 in diploid and hexaploid wheat. Crop Sci., 50: 2464-2474.

تعريف وتقييم مصادر المقاومة لصدأ السـاق في بعض التراكيب الوراثية المصرية

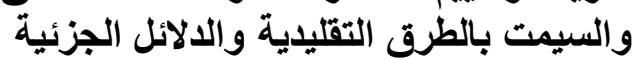

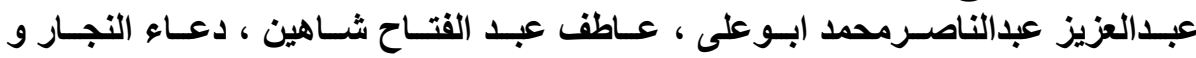

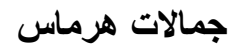

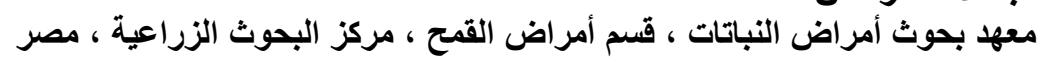

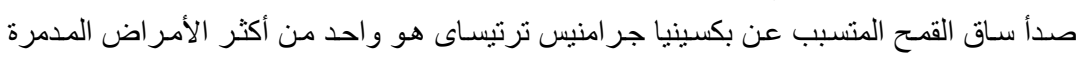

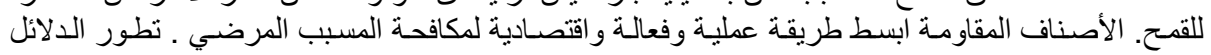

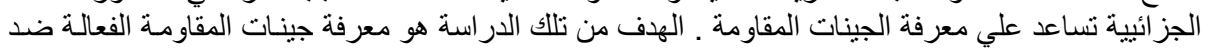

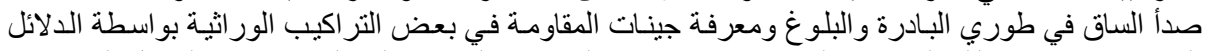

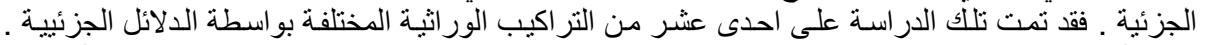

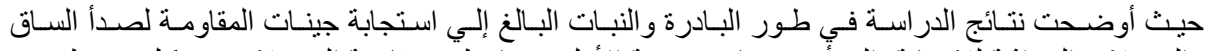

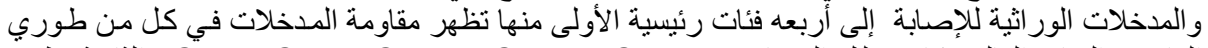

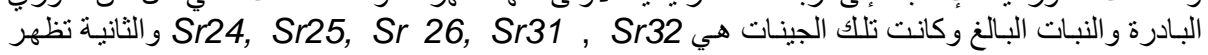

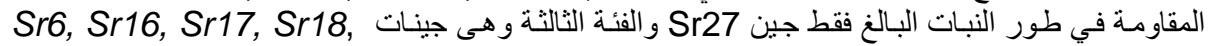
و Sr21, Sr22, Sr23, Sr28, Sr29, Sr30, Sr33, Sr34, Sr35, Sr36 ,

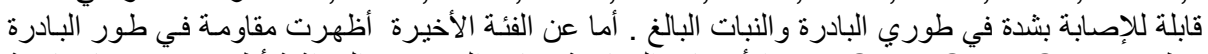

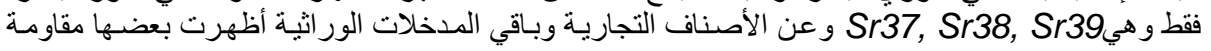

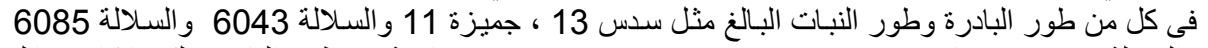

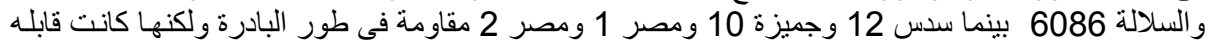

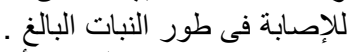

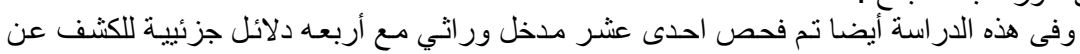

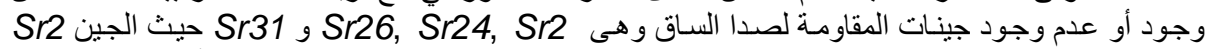

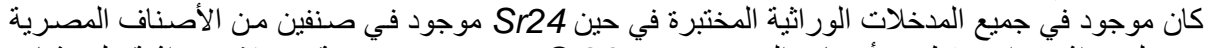
ومدخل وراثى و واحد فقط من أصناف السيمت ـ وعن Sr26 تم تحديده في تسعة مدخلات ور اثئة ولم يشاهد 
Abu Aly, A. A. M. et al.

في باقي الأصناف الذختبرة وعن الجين Sr31 تم تحديده في سبعة مدخلات وراثية بينما لم يثاهد في باقي

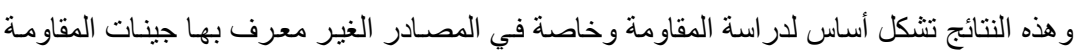
المدخلات التي تساعد المربي في الحصول علي اصناف مقاومه بو اسطة الذايل الجزئيية. 